\title{
Current status of research on exosomes in general, and for the diagnosis and treatment of kidney cancer in particular
}

Weipu Mao ${ }^{1,2^{*}+}$, Keyi Wang ${ }^{1 \dagger}$, Zonglin $\mathrm{Wu}^{1 \dagger}$, Bin $\mathrm{Xu}^{2^{*}}$ and Ming Chen ${ }^{2^{*}}$

\begin{abstract}
Kidney cancer is a common urological tumour. Owing to its high prevalence and mortality rate, it is the third most malignant tumour of the urinary system, followed by prostate and bladder cancers. It exerts a high degree of malignancy, and most of the distant metastasis occurs at an early stage; it is insensitive to chemoradiotherapy and easily develops drug resistance. The current treatment for kidney cancer mainly includes surgery, interventional embolization and targeted therapy; however, the treatment efficacy is poor. In recent years, the role of exosomes as mediators of intercellular communication and information exchange in the tumour microenvironment in tumour pathogenesis has attracted much attention. Exosomes are rich in bioactive substances such as nucleic acids, proteins and lipids and are involved in angiogenesis, immune regulation, drug resistance, formation of pre-metastatic niche, invasion and metastasis. This article reviews the ongoing research and applications of exosomes for the diagnosis and treatment of kidney cancer.
\end{abstract}

Keywords: Biomarker, Exosomes, Renal cell carcinoma, Therapy

\section{Background}

Kidney cancer, also known as renal cell carcinoma (RCC), is one of the most common malignancies of the urinary tract, and its incidence has increased at a rapid rate of $2 \%$ per year over the past two decades $[1,2]$. In 2018 , approximately 400,000 new cases and 170,000 deaths owing to kidney cancer were reported worldwide [3]. In 2015 , approximately 74,000 new cases and 27,000 deaths owing to kidney cancer were reported in China [4]. Kidney cancer is insensitive to radiotherapy and chemotherapy, and surgery remains the mainstay of treatment for kidney cancer. However, approximately $30 \%$ of patients

*Correspondence: maoweipu88@163.com; njxb1982@126.com; mingchenseu@126.com

†Weipu Mao, Keyi Wang and Zonglin Wu contributed equally to this work.

${ }^{2}$ Department of Urology, Affiliated Zhongda Hospital of Southeast

University, No. 87 Dingjiaqiao, Hunan Road, Gulou District,

Nanjing 210009, China

Full list of author information is available at the end of the article with kidney cancer develop metastasis on initial diagnosis, and approximately $25 \%$ of patients with localized kidney cancer may develop local recurrence or distant metastasis after surgery $[5,6]$. Owing to recurrence or distant metastasis, the 5-year survival rate of patients with advanced kidney cancer is extremely low, approximately $5-10 \%[7,8]$.

Exosomes are small extracellular vesicles composed of a lipid bilayer membrane structure; they are actively secreted by normal and cancer cells in the body and contain proteins, nucleic acids, lipids and other bioactive substances $[9,10]$. Exosomes play an important role in the exchange of information between cells by releasing bioactive substances that fuse with receptor cell membranes or bind to cell surface receptors [11, 12]. Studies have demonstrated that exosomes play an important role in the development, diagnosis and treatment of kidney, prostate, bladder and breast cancers and serve potential original author(s) and the source, provide a link to the Creative Commons licence, and indicate if changes were made. The images or other third party material in this article are included in the article's Creative Commons licence, unless indicated otherwise in a credit line to the material. If material is not included in the article's Creative Commons licence and your intended use is not permitted by statutory regulation or exceeds the permitted use, you will need to obtain permission directly from the copyright holder. To view a copy of this licence, visit http://creativecommons.org/licenses/by/4.0/. The Creative Commons Public Domain Dedication waiver (http://creativecommons.org/publicdomain/zero/1.0/) applies to the data made available in this article, unless otherwise stated in a credit line to the data. 
clinical applications as tumour markers, therapeutic targets and drug nanocarriers in clinical settings [13-15].

This article reviews the ongoing research and applications of exosomes for the diagnosis and treatment of kidney cancer.

\section{Overview of exosomes}

Exosomes are nanoscale biological vesicles released into surrounding body fluids upon fusion of multivesicular bodies and the plasma membrane; they are produced and secreted autonomously by living cells in vivo and are the smallest extracellular vesicles $[16,17]$. Exosomes are subgroups of extracellular vesicles with an average diameter of about $30-100 \mathrm{~nm}[18,19]$. Exosomes originate from the intracellular body structure, which influences the composition of exosome contents after interaction with other intracellular vesicles and organelles [20]. Exosomes were previously considered non-functional substances until 2007, when it was discovered that exosomes may act as 'messengers' that carry genetic material for the exchange of intercellular information and act within the recipient cells, suggesting that exosomes can be involved in intercellular information exchange [21-23]. The membrane structure of exosomes is resistant to exogenous proteases and RNA enzymes, thus resulting in more stable intracellular functional proteins, messenger RNAs (mRNAs) and microRNAs (miRNAs) that make exosomes a sensitive marker for disease diagnosis [24, 25]. In many diseases, exosomes can function by altering cellular or tissue states, and exosome-related assays can be used as effective and non-invasive methods for disease diagnosis and monitoring $[9,10]$. In addition, the study of molecular mechanisms related to exosome-mediated intercellular material exchange will also provide a theoretical basis for the development of exosome-related therapies [26, 27].

\section{Composition of exosomes}

As observed under the electron microscope, exosomes are hemispherical structures with a lipid bilayer membrane [28]. Exosomes are composed of various components, mainly including proteins, lipids and nucleic acids (Table 1), and are abundantly present in body fluids, including blood, tears, urine, saliva, milk and ascites [38] (Fig. 1). Proteins mainly include tetraspanin, heat shock proteins, MVB formation, membrane transport and fusion proteins, antigen presentation, adhesion molecules, lipid raft and cytoskeletal proteins, which participate in the fusion of cell membranes and release of exosomes [29-31]. Lipids mainly include cholesterol, ceramide, phosphatidylserine, phosphatidylinositol, phosphatidylcholine, sphingomyelin and ganglioside, which are involved in the biological activity of exosomes [3234]. Nucleic acids mainly include DNA, mRNA, miRNA, long non-coding RNA (lncRNA) and circular RNA (circRNA), which participate in the transmission of genetic information and diagnosis of diseases [35-37]. The specific components of exosomes are displayed in Table 1.

\section{Formation of exosomes}

The exact mechanism of exosome formation remains poorly understood, and the endosomal sorting complex required for transport (ESCRT) is a classical pathway [39, 40] (Fig. 2). The two main steps in the formation of exosomes are as follows: First, the cell membrane sags inward to form the early endosomes with accumulated luminal vesicles (ILV), and the endosomes are wrapped with proteins, lipids and nucleic acids synthesised by the cells; the endosomal membrane is depressed to bud inward to form tubular vesicles (intraluminal vesicles), that is, early endosomes (EEs) [41, 42]. Subsequently, the depressed membrane matures into multivesicular bodies (MVBs) with dynamic subcellular structures, that is, late endosomes (LEs), which can expose the transmembrane

Table 1 Composition of exosomes

\begin{tabular}{lll}
\hline Type & & Cargoes \\
\hline Protein & Tetraspanin & Reference \\
& Heat shock protein & Hsp70, Hsp90, etc \\
& MVB formation & ALIX, TSG101, etc \\
& Membrane transport and fusion proteins & Rab, Annexins (I, II, IV, V, VI), etc \\
& Antigen presentation & MCH I, MCH II, etc \\
& Adhesion molecules & integrins, ICAM-1, CD146, etc \\
& Lipid raft & LAPA, Flotillin-1, Cholesterol, etc \\
& Cytoskeletal proteins & \\
Lipids & Cholesterol, ceramide, phosphatidylserine, phosphatidylinositol, & \\
& phosphatidylcholine, sphingomyelin, ganglioside, etc & \\
Nucleic acids & DNA, mRNA, miRNA, IncRNA, circRNA, etc & \\
\hline
\end{tabular}




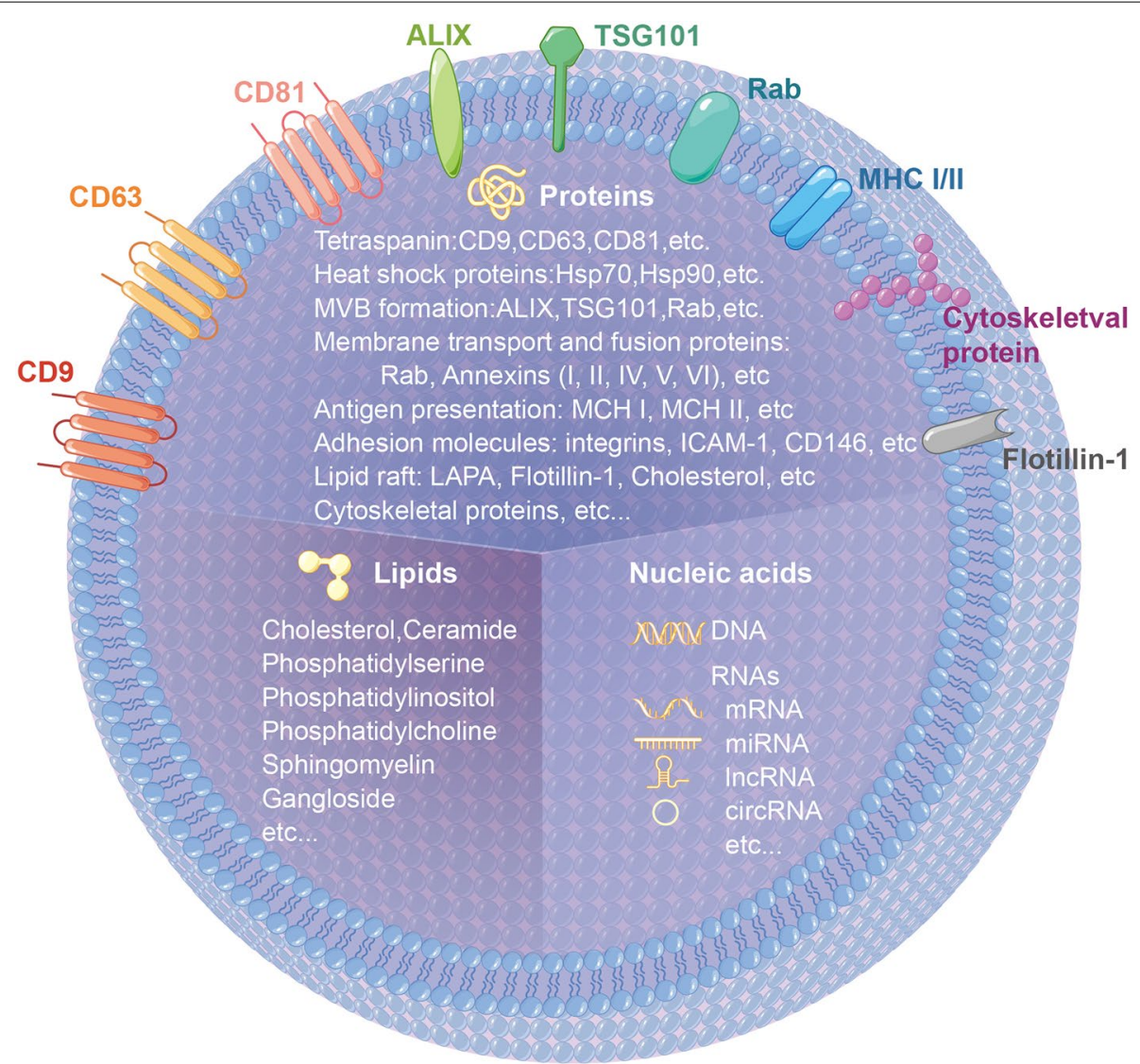

Fig. 1 The hallmarks and cargos of exosomes. Exosomes are hemispherical structures with lipid bilayer membrane under electron microscope. Exosomes are composed of various components, mainly including proteins, lipids and nucleic acids

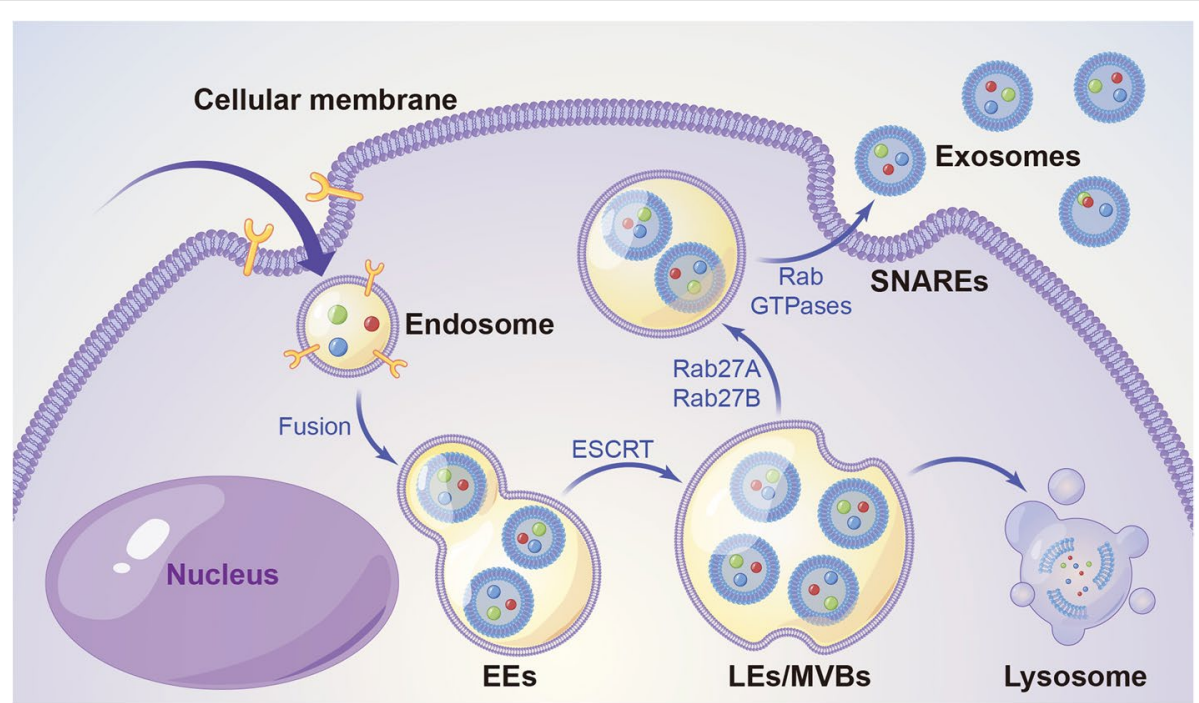

Fig. 2 Exosome biogenesis and secretion within endosomal system by the endosomal sorting complex required for transport (ESCRT) pathway. Early endosomes (EEs) are formed by the fusion of endsomes. Subsequently, EEs depend on ESCRT to form multivesicular late endosomes (LEs)/ bodies (MVBs). Rab27a and Rab27b direct the movement of LEs/MVBs toward the cell periphery, the SNARE complex helps LEs/MVBs fuse with the plasma membrane to release exosomes, and the rest of LES/MVBs are degraded by lysosomes 
protein domain of the cytoplasm and release multiple vesicle structures into the extracellular environment upon fusion with the plasma membrane to form exosomes. Rab27a and Rab27b direct the movement of LEs/MVBs toward the cell periphery, the SNARE complex helps LEs/MVBs fuse with the plasma membrane to release exosomes, and the rest of LEs/MVBs are degraded by lysosomes [43, 44].

\section{Secretion of exosomes}

Exosomes are secreted extracellularly through exocytosis upon the fusion of intercalated compartments with plasma membrane, which is the most basic and common process in cells [45]. However, in T cells and mast cells, this fusion is dependent on calcium ions for activation [46]. Most intracellular membrane fusions occur through specific protein mechanisms, such as N-ethylmaleimidesensitive factor (NSF) for soluble factors and soluble NSF adhesion protein (SNAP) and SNAP adhesion protein receptor (SNARE) for membrane complex factors [47]. The two membranes in which fusion occurs should contain the corresponding SNAREs, namely vesicular SNARE (v-SNARE) and target SNARE (t-SNARE) $[48,49]$. In addition, exosome secretion is controlled by Ras-associated GTP-binding protein 27a (Rab27a) and Rab27b [50, 51]. Synaptic binding protein-like 4 (SYTL4) and exophilin 5 (EXPH5) can inhibit Rab27a and Rab27b, leading to exosome secretion [51]. The exact mechanism of regulation of exosome secretion remains unclear, and the role of the above-mentioned molecules in exosome secretion requires further investigation.

\section{Function of exosomes}

Exosomes are released by different cell types and can regulate the biological activity of target cells by transporting proteins, lipids and nucleic acids. They play a role in various biological processes such as angiogenesis, antigen presentation, apoptosis and inflammation [17]. They act by transferring informative substances, thus influencing physiological and pathological processes involved in cancer, neurodegenerative diseases, infections and autoimmune diseases [52-56]. Exosomes affect the recipient cells through two pathways [57]. The first pathway involves ligand-receptor interactions between exosomes and recipient cells, without internalising the exosome or its contents into the target cell. This pathway can regulate the activation or inhibition of target cell signalling pathways. The second pathway involves the entry of exosomes into cells through membrane fusion or endocytosis, wherein their components are taken up and released into the cytoplasm, thus affecting the host cells by regulating specific gene expression and signalling pathways and ultimately leading to changes in the cell function or phenotype.

\section{Detection of exosomes}

In recent years, with the progress of research on exosomes in tumours, various technologies for exosome detection have been introduced that focus on the following three aspects: isolation and enrichment, identification and content analysis [58-62]. In addition, some researchers have developed various kits for the diagnosis and prognostic risk assessment of tumours based on the composition of exosomes [56, 63-66]. Development of such detection kits is a major clinical breakthrough in the field of early tumour diagnosis and provides an effective test for clinical diagnosis and the assessment of efficacy. However, there is a lack of a unified gold-standard method for exosome detection, which makes it difficult to be widely promoted in clinical settings. Therefore, it is necessary to discover a uniform and clinically recognised exosome detection technology.

\section{Exosomes and kidney cancer} Involvement in the formation of tumour microenvironment The tumour microenvironment is a key factor in the formation of tumours, and tumour cells can interact with their microenvironment to promote tumorigenesis and progression [67]. Exosomes exhibit certain characteristics of tissue and organ cellophilia, and the expression of this tendency is related to the expression of integrins on the surface of exosomes [68]. The establishment of pre-metastatic ecological niche is a complex process that involves the binding of exosomes secreted by cancer cells to the stromal cells of target organs, leading to the reprogramming of target cells, activation of signalling pathways and ultimately the establishment of a pre-metastatic microenvironment in target organs, thus providing the prerequisite for tumour metastasis $[69,70]$. Exosomes are considered the main mediators of cell-cell interactions in the tumour microenvironment and are involved in promoting tumour cell invasion, angiogenesis and immunosuppression [71-75]. The role of exosomal constituents in kidney cancer are shown in Fig. 3.

\section{Contribution to angiogenesis}

During tumorigenesis, tumour cells require a large supply of nutrients and oxygen to maintain rapid cell growth and reproduction. The formation of new blood vessels in the primary tumour foci provides more nutrients for the growth and spread of tumour cells [76, 77]. Tumour cells promote angiogenesis by activating endothelial cells [78]. Endothelial cells secrete exosomes rich in vascular endothelial growth factor (VEGF), fibroblast growth factor (FGF), angiopoietin-1 (ANGPT1), ephrin A3 


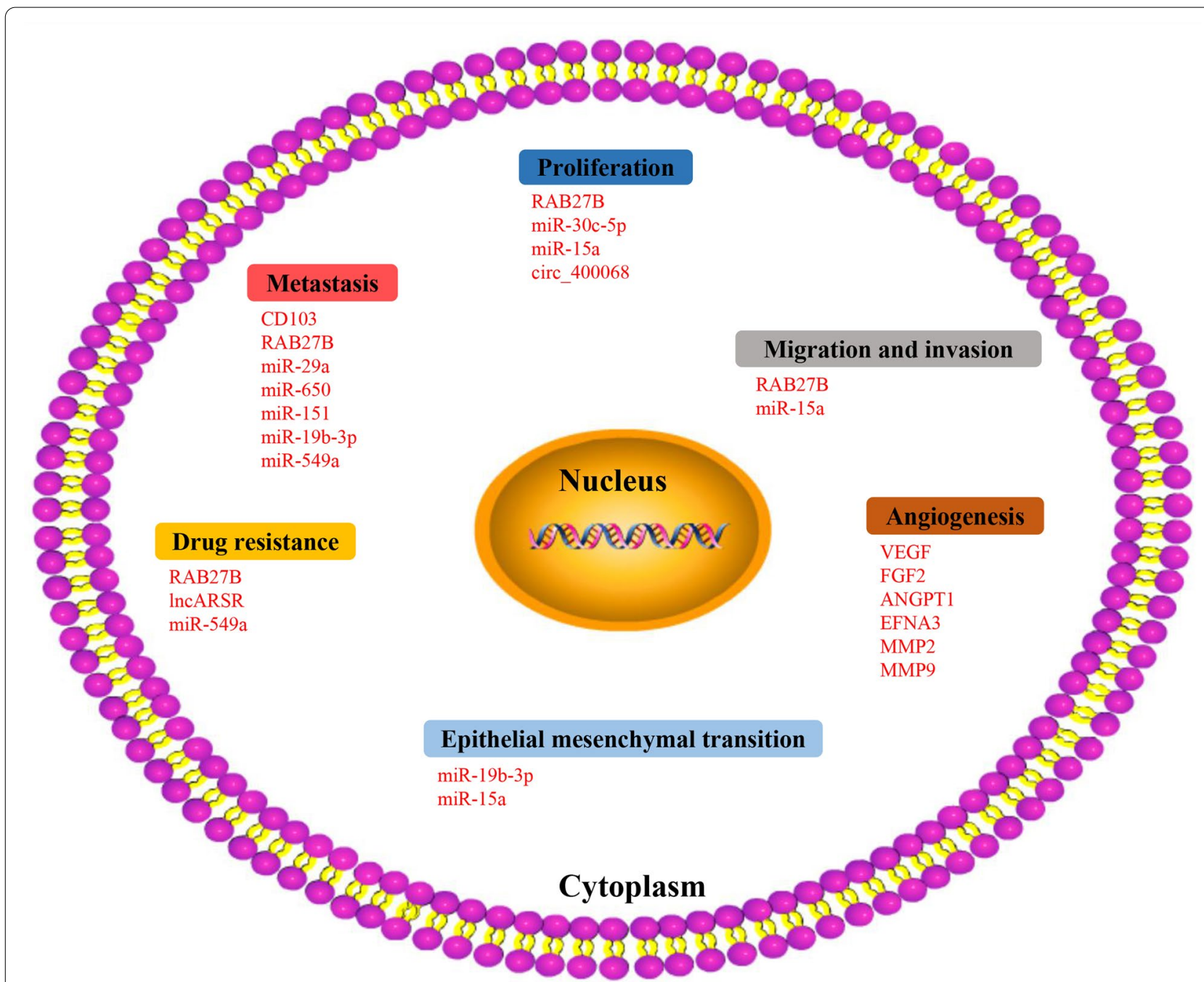

Fig. 3 Role of exosomal constituents in kidney cancer. Exosomal component sare involved in the proliferation, migration and invasion, metastasis, angiogenesis, drug resistance, and epithelial mesenchymal transition (EMT) of kidney cancer

(EFNA3), matrix metallopeptidase 2 (MMP2), matrix metallopeptidase 9 (MMP9) and azurocidin 1 (AZU1), which can stimulate the production of adjacent tumour blood vessels [78-82]. Grange et al. [70] verified that a subset of CD105-expressing tumour-initiating cells in human kidney cancer released microvesicles, which triggered angiogenesis and promoted the formation of pre-metastatic niches. Hou et al. [72] demonstrated that oncogenic miR-27a delivered by exosomes can bind to secreted frizzled-related protein 1 (SFRP1) and promote angiogenesis in kidney cancer. Tyrosine kinase inhibitor (TKI)-resistant kidney cancer can secrete low levels of exosomal miR-549a to induce vascular permeability and angiogenesis to promote kidney cancer metastasis [83]. $\mathrm{Li}$ et al. [84] found that ApoC1 transfer from kidney cancer cells to vascular endothelial cells through exosomes promoted angiogenesis and enhanced the migration and invasion of human umbilical vein endothelial cells (HUVEC) cells by activating signal transducer and activator of transcription 3 (STAT3). In addition, exosomes with high expression of carbonic anhydrase IX (CA IX) are associated with kidney cancer revascularisation [85]. The establishment of a vascular network is not only essential for the normal growth of tumour tissues but also provides an important channel for tumour invasion [86].

\section{Contribution to immune escape}

Myeloid-derived suppressor cells (MDSCs) exert potent inhibitory effects on several immune cells, and their high concentration aggregation in the tumour microenvironment is one of the reasons for the formation of tumour immune escape [87, 88]. It was found that Hsp70 was abundantly present in exosomes secreted by mouse 
kidney cancer cells (Renca cells), upregulated the expression of arginase 1 (ARG-1), iNOS, interleukin 6 (IL-6) and VEGF and induced the expression of MDSCs by phosphorylating STAT3 (p-STAT3) pathway, thus promoting tumour growth $[75,89]$.

Natural killer (NK) cells are the main host defence factors against kidney cancer cells and can exert antitumour effects by either directly mediating cytotoxic activity through degranulation or promoting anti-tumour activity and producing immunomodulatory cytokines [90-92]. Xia et al. [93] found that exosomes of kidney cancer origin induced defective NK cell function through transforming growth factor-beta (TGF- $\beta$ )/SMAD signalling pathway to evade natural immunity.

Exosomes secreted by kidney cancer cells can induce immune responses in $\mathrm{T}$ cells to trigger apoptosis of activated $\mathrm{T}$ lymphocytes by activating the caspase pathway. They can diminish the cytotoxicity of NK cells and reduce the production of IL-2, interferon gamma (IFN- $\gamma$ ), IL-6 and IL-10, which contribute to the immune escape and promote the development of kidney cancer [77, 94, 95]. In addition, exosomes isolated from human renal adenocarcinoma ACHN cells contain Fas ligands, which inhibit the action of the human immune system by inducing apoptosis of $\mathrm{CD} 8+\mathrm{T}$ cells and ultimately help cancer cells in achieving immune escape [96].

\section{Involvement in cancer cell invasion and metastasis}

A key molecular event in the development of target organ/tissue metastasis by tumours is the formation of tumour pre-metastatic niches [97]. Tumour pre-metastatic niches are defined as some molecular and cellular changes in metastatic-designated organs/tissues that can facilitate the colonisation of target organs/tissues by circulating tumour cells and promoting distant tumour metastasis [98]. In recent years, secretory components and cells found in distant metastatic tissues of different tumour animal models, including soluble factors, exosomes, vesicles and MDSCs, have confirmed the presence of tumour pre-metastatic niches in most types of malignancies [99, 100]. Exosomes can alter the target cell function through substances they carry; tumour-derived exosomes that act on epithelial cells lead to epithelialmesenchymal transition (EMT), which is important in tumour metastasis [101].

\section{Role of exosomes in the diagnosis of kidney cancer Proteins}

Raimondo et al. [73] identified 261 and 186 proteins by isolating urinary exosomes from normal patients and patients with kidney cancer, respectively, and most proteins were membrane-associated or cytoplasmic. Among these proteins, the expression of MMP9, ceruloplasmin
(CP), podocalyxin like (PODXL), carbonic anhydrase IX (CAIX) and dickkopf 4 (DKK4) in urinary exosomes was higher in patients with kidney cancer than that in normal patients, and the expression of CD10, extracellular matrix metalloproteinase inducer (EMMPRIN), dipeptidase 1 (DPEP1), syntenin 1 and aquaporin 1 (AQP1) in urinary exosomes was higher in normal patients than that in patients with kidney cancer. These proteins may serve as potential markers of kidney cancer. Wang et al. [68] investigated the effect of exosomes isolated from cancer stem cells (CSCs) of 76 patients with metastatic RCC and 133 patients with localised RCC and found that CD103+ played a role in directing CSC exosomes to target cancer cells and organs. In addition, Tsuruda et al. [102] found that Rab27b protein can play an oncogenic role in renal cancer and sunitinib resistance through exosome-independent function.

\section{mRNA}

mRNAs are a class of single-stranded RNAs that carry genetic information and can direct protein synthesis; they are transcribed from a strand of DNA as a template [103, 104]. Exosomes can carry and transport large amounts of mRNA to function in the recipient cells [23]. Grange et al. [70] identified mRNAs implicated in tumour progression and metastasis through molecular characterisation of microvesicles, including VEGF, FGF2, ANGPT1, EFNA3, MMP2 and MMP9. In addition, Palma et al. [105] reported that the mRNA levels of glutathione s-transferase alpha 1 (GSTA1), CCAAT enhancer binding protein alpha (CEBPA) and pterin-4 alpha-carbinolamine dehydratase 1 (PCBD1) in urinary extracellular vesicles were lower in patients with RCC than those in controls, and the mRNA levels of these three genes returned to normal 1 month after nephrectomy. This demonstrates that mRNA levels in urinary extracellular vesicles serve as potential molecular markers for the diagnosis of RCC.

\section{miRNA}

miRNAs are smaller endogenous non-coding RNAs (18-24 nucleotides) that regulate protein translation after gene transcription [106, 107]. They can act as oncogenes or tumour suppressors involved in tumorigenesis $[108,109]$. Several exosomal miRNAs have been identified to be differentially expressed in patients with renal cancer and normal patients. Grange et al. [70] found that 24 miRNAs, including miR-200c and miR-650, were significantly upregulated in CD105+ microvesicles, and 33 miRNAs, including miR-100 and miR-296, were significantly downregulated, and several miRNAs such as miR29a, miR-650, and miR-151 were associated with tumour invasion and metastasis. Zhang et al. [110] found that the expression levels of miR-210 and miR-1233 in blood 
exosomes were significantly higher in patients with RCC than those in healthy subjects, and the expression levels were significantly decreased after surgical removal of the tumour. Xiao et al. [111] sequenced exosomal miRNAs from plasma samples and found that the expression level of miR-149-3p and miR-424-3p was upregulated, whereas that of miR-92a-1-5p was significantly decreased. In addition, other miRNAs were reported to be potential diagnostic biomarkers of kidney cancer [68, 83, 112-118].

\section{InCRNA}

lncRNAs are RNAs that are longer than 200 nucleotides and cannot code for proteins [119]. They can control cellular transcription and protein translation by interacting with proteins, mRNAs or miRNAs [120]. Malignant tumour cells can express specific lncRNA markers, indicating that lncRNAs can be used as disease-specific markers that are important for cancer diagnosis [121]. lncRNAs are abundantly expressed in exosomes and can be protected by the exosomal tegument with higher stability [122, 123]. Similar to miRNAs, IncRNAs play an important role in the growth, proliferation, invasion and metastasis of cancer cells [124]. Qu et al. [125] demonstrated that exosome-transmitted lncARSR promoted AXL and c-MET expression in RCC cells by competitively binding to $\mathrm{miR}-34 / \mathrm{miR}-449$, thereby promoting sunitinib resistance. Exosomal lncRNAs are important in tumour biology, and further studies are required to understand the role of exosomal lncRNAs in renal cancer.

\section{circRNA}

CircRNAs are a newly discovered type of non-coding RNAs that form a covalently closed continuous loop structure that originates from exons or introns by specific selective shearing [126-128]. It has been found that a large number of circRNAs can be detected in exosomes. circRNAs function as miRNA sponges during gene regulation $[129,130]$. Based on the circRNA expression array data, Xiao et al. [131] found that circ_400068 was significantly upregulated in exosomes derived from RCC. At present, circRNAs in exosomes derived from renal cancer cells have been investigated in a relatively small number of studies, and therefore, further investigation is required. Potential biomarkers derived from exosomes that have been validated in kidney cancer are listed in Table 2. Figure 3 demonstrates the role of exosomal constituents in kidney cancer.

\section{The role of exosomes in kidney cancer treatment Tumour drug resistance}

Tumour drug resistance is one of the main reasons for the failure of clinical treatment of tumours. Drug-resistant tumour cells can secrete exosomes that contain the genetic information of multiple drug resistance-associated proteins, which in turn cause other tumour cells to acquire drug resistance [132, 133]. Several receptor tyrosine kinases associated with angiogenesis and tumour microenvironment are overexpressed mainly owing to the inactivation of Von Hippel-Lindau (VHL) tumour suppressor genes in renal cancer; therefore, TKIs, including sunitinib, have become one of the first-line therapies for renal cancer [134]. However, sunitinib resistance has made the clinical benefit of sunitinib treatment limited at present [135]. Qu et al. [125] found that drug-resistant cells in nephropathy transmitted lncARSR to other cells through exosomes, causing them to develop drug resistance, and lncARSR promoted AXL/c-MET expression by competitively binding to miR-34/miR-449. MET expression, which in turn promoted lncARSR expression as positive feedback, further promoted drug resistance in renal cancer cells. In addition, Tsuruda et al. [102] found that Rab27b can play an oncogenic role in sunitinib resistance in renal cancer through exosome-independent function. The above-mentioned study demonstrates that exosomes mediate the development of drug resistance in tumour cells, which can not only provide novel therapeutic targets for patients but also predict the responsiveness of patients to anti-tumour drugs through the detection of exosomal markers, thus providing an important reference for individualised treatment of kidney cancer $[44,136]$.

\section{Drug carriers}

Owing to their lipid bilayer membrane structure, exosomes can protect RNA present inside the membranes from degradation by RNA enzymes, and owing to their smaller particle size and deformability, they can cross the biological membranes more easily, thus facilitating precise delivery of therapeutic genes to the target cells $[137,138]$. Exosomes can mediate the transfer of genetic material, thus altering the biological activity of recipient cells [139]. Exosomes can carry various therapeutic substances, including RNAs and antisense oligonucleotides [24]. Exosomes can deliver therapeutic substances directly to target organs through different biological barriers, for example, macrophage-derived exosomes can effectively cross the blood-brain barrier to deliver protein-like substances [140]. Ligand enrichment on engineered exosomes can also be used to induce or inhibit signalling in the receptor cells for targeting exosomes to specific cells [141]. In addition, exosomes can be effectively loaded with chemotherapeutic drugs with low toxic side effects. Therefore, they can serve as well-tolerated and promising drug carriers [142, 143]. Currently, exosomes are considered important drug delivery carriers for the treatment of cardiovascular 
Table 2 Exosomes derived potential biomarker for kidney cancer

\begin{tabular}{|c|c|c|c|c|c|c|}
\hline Type & Source & Cohorts & Method & Cargoes & Year & Reference \\
\hline \multirow[t]{3}{*}{ Protein } & Urine & 29 RCC, 23 health & LC-MS/MS, western blotting & $\begin{array}{l}\text { MMP9, CP, PODXL, CAIX } \\
\text { and DKK4; CD10, EMMPRIN, } \\
\text { DPEP1, Syntenin } 1 \text { and AQP1 }\end{array}$ & 2013 & Raimondo et al. [73] \\
\hline & Serum & $\begin{array}{l}76 \text { metastatic RCC, } 133 \\
\text { located RCC }\end{array}$ & Flow cytometry & CD103 & 2019 & Wang et al. [68] \\
\hline & Supernatants & A498 cell & ExoELISA-ULTRA CD63 kit & RAB27B & 2020 & Tsuruda et al. [102] \\
\hline \multirow[t]{2}{*}{ mRNA } & Supernatants & Cancer stem cells & Microarray, qRT-PCR & $\begin{array}{l}\text { VEGF, FGF2, ANGPT1, EFNA3, } \\
\text { MMP2 and MMP9 }\end{array}$ & 2011 & Grange et al. [70] \\
\hline & Urine & 46 RCC, 22 health & Microarray, qRT-PCR & GSTA1, CEBPA, PCBD1 & 2016 & Palma et al. [105] \\
\hline \multirow[t]{12}{*}{ miRNA } & Supernatants & Cancer stem cells & Microarray, qRT-PCR & $\begin{array}{l}\text { miR-200c, miR-650, miR-100, } \\
\text { miR-296, miR-29a, miR-650, } \\
\text { miR-151 }\end{array}$ & 2011 & Grange et al. [70] \\
\hline & Urine & 81 RCC, 33 health & Microarray, qRT-PCR & $\begin{array}{l}\text { miR0126-3p, miR-449a, } \\
\text { miR-34b-5p, miR-486-5p, } \\
\text { miR-30c-5p }\end{array}$ & 2016 & Butz et al. [118] \\
\hline & Plasma & $\begin{array}{l}44 \text { metastatic RCC, } 65 \text { meta- } \\
\text { static RCC }\end{array}$ & RNA-sequencing, qRT-PCR & $\begin{array}{l}\text { miR-let-7i-5p, miR-26a-1-3p, } \\
\text { miR-615-3p }\end{array}$ & 2017 & Du et al. [113] \\
\hline & Serum & 82 RCC, 80 health & qRT-PCR & miR-210, miR-1233 & 2018 & Zhang et al. [110] \\
\hline & Supernatants & HK-2 cell, 786-O cell & qRT-PCR & miR-205 & 2018 & Crentsil et al. [115] \\
\hline & Serum & $\begin{array}{l}40 \text { RCC, } 30 \text { health, } 5 \text { lung } \\
\text { metastasis RCC }\end{array}$ & Microarray, qRT-PCR & miR-210 & 2018 & Wang et al. [117] \\
\hline & Serum & $\begin{array}{l}76 \text { metastatic RCC, } 133 \\
\text { located RCC }\end{array}$ & qRT-PCR & miR-19b-3p & 2019 & Wang et al. [68] \\
\hline & Urine & 70 early-stage RCC, 30 health & NGS, qRT-PCR & $\operatorname{miR}-30 c-5 p$ & 2019 & Song et al. [112] \\
\hline & Urine/ Supernatants & $\begin{array}{l}\text { Mice urine; mouse and } \\
\text { human tRCC cell lines }\end{array}$ & qRT-PCR & miR-204-5p & 2019 & Kurahashi et al. [114] \\
\hline & Plasma & $\begin{array}{l}5 \text { RCC, } 5 \text { health; } 22 \text { RCC, } 16 \\
\text { health }\end{array}$ & RNA-sequencing; qRT-PCR & $\begin{array}{l}\text { miR-92a-1-5p, miR-149-3p, } \\
\text { miR-424-3p }\end{array}$ & 2020 & Xiao et al. [111] \\
\hline & Supernatants & 786-O cell, 786-O-SR cell & qRT-PCR & miR-549a & 2021 & Xuan et al. [83] \\
\hline & Plasma & ACHN cell & Microarray, qRT-PCR & miR-15a & 2021 & Li et al. [116] \\
\hline IncRNA & Plasma & 71 advanced RCC, 32 health & qRT-PCR & IncARSR & 2016 & Qu et al. [125] \\
\hline circRNA & Plasma & $28 \mathrm{RCC}$ & circRNA microarray & circ_400068 & 2020 & Xiao et al. [131] \\
\hline
\end{tabular}

diseases and pancreatic cancer [35, 144]; however, their role in kidney cancer requires further investigation [145].

\section{Tumour vaccines}

Compared with conventional vaccines, the vaccines developed using exosomes derived from tumour cell secretion may exert incomparable effects with higher affinity [146]. Exosomes secreted by tumour cells can present tumour-associated antigens and induce the development of immunity against tumours [94]. Zhang et al. found that IL-12-anchored kidney cancer cellderived exosomes induced the production of more cytotoxic $\mathrm{T}$ lymphocytes specific for kidney cancer antigens and improved anti-tumour effects [147]. They further constructed an enhanced immunogenic EXO-IL-12 vaccine capable of stably expressing kidney cancer-specific antigen G250, immune-associated protein and GPIIL-12, which can significantly enhance the proliferation and activation of $\mathrm{T}$ lymphocytes in vitro and exert an induced antigen-specific killing effect [74, 148]. Another study found that mice with kidney cancer vaccinated with tumour exosome-loaded dendritic cell (DC-TEX) vaccine had a longer survival period than that of mice vaccinated with tumour cell lysate-loaded dendritic cell vaccine [149]. Exosomes that are loaded and delivered with tumour suppressor genes that inhibit tumour cell growth provide necessary conditions for the development of exosomal tumour vaccines [150-152].

\section{Conclusion}

Early diagnosis of kidney cancer is one of the key factors in improving the survival rate of patients. Exosomes may benefit early diagnosis. Exosomes secreted by kidney cancer cells are abundantly present in blood, urine and other body fluids, thus providing advantages such as easy availability, non-invasive examination and tumour specificity. Owing to their small size, high mobility and lipid bilayer structure, they can 
easily passthrough biological membranes and protect rich bioactive substances present inside the membranes from degradation; therefore, exosomes have become a prime focus of research. Tumour-derived exosomes carry a large number of substances, including proteins, nucleic acids and lipids, which can alter the biological behaviour of target cells and participate in the development of kidney cancer. Numerous studies have found that the expression of exosomes is significantly different in patients with kidney cancer and normal subjects. Exosomes play an important role in the infiltration and metastasis of kidney cancer and also participate in tumour drug resistance and immune escape. Studies related to exosomes provide new ideas for the diagnosis and treatment of kidney cancer and offer adequate developmental prospects. However, studies on exosomes derived from renal cancer cells are mostly retrospective, and the tissue types mostly include renal clear cell carcinoma. To promote the application of exosomes in clinical settings, more extensive studies combined with clinical trials are required, and future studies should include increased sample sizes and different tissue types and adopt a prospective study design, which will be more convincing and provide substantial medical data support for clinical translation. In addition, the study of exosomes in kidney cancer is relatively independent and none of the molecules identified seem to have been repeatedly validated in different studies, which requires more prospective clinical trials leading to more reproducible biomarkers. Moreover, further investigation is required for developing exosome-mediated tumour vaccines and understanding the effect and mechanism of drug resistance on targeted therapy for kidney cancer.

\footnotetext{
Abbreviations

ALIX: ALG-2 interacting protein X; ANGPT1: Angiopoietin-1; AQP1: Aquaporin 1; ARG-1: Arginase 1; AZU1: Azurocidin 1; CA IX: Carbonic anhydrase IX; CEBPA: CCAAT enhancer binding protein alpha; circRNA: Circular RNA; CP: Ceruloplasmin; CSCs: Cancer stem cells; DKK: 4dickkopf 4; DPEP1: Dipeptidase 1; EEs: Early endosomes; EFNA3: Ephrin A3; EMMPRIN: Extracellular matrix metalloproteinase inducer; EMT: Epithelial-mesenchymal transition; ESCRT : Endosomal sorting complex required for transport; EXPH5: Exophilin 5; FGF: Fibroblast growth factor; FLOT1: Flotillin-1; GSTA1: Syntenin 1 and glutathione s-transferase alpha 1; Hsp: Heat shock proteins; HUVEC: Human umbilical vein endothelial cells; ICAM-1: Intercellular adhesion molecule-1; IFN-ү: Interferon gamma; IL-6: Interleukin 6; LEs: Late endosomes; IncRNA: Long non-coding RNA; MDSCs: Myeloid-derived suppressor cells; MHC: Major histocompatibility complex; miRNAs: microRNAs; MMP2: Matrix metallopeptidase 2; MMP9: Matrix metallopeptidase 9; mRNAs: Messenger RNAs; MVBs: Multivesicular bodies; NK: Natural killer; NSF: N-ethylmaleimide-sensitive factor; PCBD1: Pterin-4 alpha-carbinolamine dehydratase 1; PODXL: Podocalyxin like; Rab: Ras-associated GTP-binding; RCC: Renal cell carcinoma; SFRP1: Secreted frizzled-related protein 1; SNAP: Soluble NSF adhesion protein; SNARE: SNAP adhesion protein receptor; STAT3: Signal transducer and activator of transcription 3; SYTL4: Synaptic binding protein-like 4; TGF- $\beta$ : Transforming growth factor-beta; TKI:Tyrosine kinase inhibitor;TSG101:Tumour susceptibility gene
}

101; t-SNARE: Target SNARE; VEGF: Vascular endothelial growth factor; VHL: Von Hippel-Lindau; v-SNARE: Vesicular SNARE.

\section{Acknowledgments}

We thank Home for Researchers (www.home-for-researchers.com) optimizing the figures and Bullet Edits (http://www.bulletedits.cn/) for editing this manuscript.

\section{Authors' contributions}

WM, KW and ZW contributed equally to this work and share first authorship. Conceptualization, WM, BX and $M C$; writing —original draft preparation, $\mathrm{WM}_{\text {; }}$ writing - review and editing, $B X$ and $M C$; visualization, $K W$ and $Z W$; supervision, KW and ZW; funding acquisition, WM and MC. All authors read and approved the final manuscript.

\section{Funding}

This study was supported by the Scientific Research Foundation of Graduate School of Southeast University (YBPY2173), Postgraduate Research \& Practice Innovation Program of Jiangsu Province (KYCX21_0156), Jiangsu Provincial Key Research and Development Program (BE2019751), Innovative Team of Jiangsu Provincial (2017XKJQW07), and The National Key Research and Development Program of China (SQ2017YFSF090096).

\section{Availability of data and materials}

The datasets used and analysed during the current study are available from the corresponding author on reasonable request.

\section{Declarations}

Ethics approval and consent to participate

Not applicable.

\section{Consent for publication}

We have obtained consents to publish this paper from all the participants of this study.

\section{Competing interests}

We declare that there are no conflicts of interest between authors.

\section{Author details}

'Department of Urology, Shidong Hospital of Yangpu District, No. 999 Shiguang Road, Yangpu District, Shanghai 200438, China. ${ }^{2}$ Department of Urology, Affiliated Zhongda Hospital of Southeast University, No. 87 Dingjiaqiao, Hunan Road, Gulou District, Nanjing 210009, China.

Received: 18 August 2021 Accepted: 23 September 2021

Published online: 28 September 2021

\section{References}

1. Siegel RL, Miller KD, Fuchs HE, Jemal A. Cancer statistics, 2021. CA Cancer J Clin. 2021:71(1):7-33.

2. Ljungberg B, Bensalah K, Canfield S, Dabestani S, Hofmann F, Hora M, et al. EAU guidelines on renal cell carcinoma: 2014 update. Eur Urol. 2015;67(5):913-24.

3. Sung H, Ferlay J, Siegel RL, Laversanne M, Soerjomataram I, Jemal A et al. Global Cancer statistics 2020: GLOBOCAN estimates of incidence and mortality worldwide for 36 cancers in 185 countries. CA Cancer J Clin. 2021;71(3):209-49.

4. Zhang $\mathrm{S}$, Sun $\mathrm{K}$, Zheng $\mathrm{R}$, Zeng $\mathrm{H}$, Wang $\mathrm{S}$, Chen $\mathrm{R}$, et al. Cancer incidence and mortality in China. J Nat Cancer Cent. 2015;2020.

5. Tannir NM, Pal SK, Atkins MB. Second-line treatment landscape for renal cell carcinoma: a comprehensive review. Oncologist. 2018;23(5):540-55.

6. Mao W, Wang K, Zhang H, Lu H, Sun S, Tian C, et al. Sarcopenia as a poor prognostic indicator for renal cell carcinoma patients undergoing nephrectomy in China: a multicenter study. Clin Transl Med. 2021;11(1):e270. 
7. Yong C, Stewart GD, Frezza C. Oncometabolites in renal cancer. Nat Rev Nephrol. 2020;16(3):156-72.

8. Bianchi M, Sun M, Jeldres C, Shariat SF, Trinh QD, Briganti A, et al. Distribution of metastatic sites in renal cell carcinoma: a population-based analysis. Ann Oncol. 2012;23(4):973-80.

9. Kalluri R, LeBleu VS. The biology, function, and biomedical applications of exosomes. Science. 2020;367(6478).

10. Kalluri R. The biology and function of exosomes in cancer. J Clin Invest. 2016;126(4):1208-15.

11. Mathieu M, Martin-Jaular L, Lavieu G, Thery C. Specificities of secretion and uptake of exosomes and other extracellular vesicles for cell-to-cell communication. Nat Cell Biol. 2019;21(1):9-17.

12. Li I, Nabet BY. Exosomes in the tumor microenvironment as mediators of cancer therapy resistance. Mol Cancer. 2019;18(1):32.

13. Nawaz M, Camussi G, Valadi H, Nazarenko I, Ekstrom K, Wang X, et al. The emerging role of extracellular vesicles as biomarkers for urogenital cancers. Nat Rev Urol. 2014;11(12):688-701.

14. Thongboonkerd V. Roles for exosome in various kidney diseases and disorders. Front Pharmacol. 2019;10:1655.

15. Halvaei S, Daryani S, Eslami SZ, Samadi T, Jafarbeik-Iravani N, Bakhshayesh TO, et al. Exosomes in Cancer liquid biopsy: a focus on breast Cancer. Mol Ther Nucleic Acids. 2018;10:131-41.

16. Tkach M, Kowal J, Thery C. Why the need and how to approach the functional diversity of extracellular vesicles. Philos Trans R Soc Lond B Biol Sci. 2018;373:1737.

17. Zhang Y, Liu Y, Liu H, Tang WH. Exosomes: biogenesis, biologic function and clinical potential. Cell Biosci. 2019;9:19.

18. Johnstone RM, Adam M, Hammond JR, Orr L, Turbide C. Vesicle formation during reticulocyte maturation. Association of plasma membrane activities with released vesicles (exosomes). J Biol Chem. 1987:262(19):9412-20

19. Yang L, Shi P, Zhao G, Xu J, Peng W, Zhang J, et al. Targeting cancer stem cell pathways for cancer therapy. Signal Transduct Target Ther. 2020;5(1):8.

20. Tkach $M$, Thery C. Communication by extracellular vesicles: where we are and where we need to go. Cell. 2016;164(6):1226-32.

21. Raposo G, Nijman HW, Stoorvogel W, Liejendekker R, Harding CV, Melief $\mathrm{CJ}$, et al. B lymphocytes secrete antigen-presenting vesicles. J Exp Med. 1996;183(3):1161-72.

22. Shimaoka M, Kawamoto E, Gaowa A, Okamoto T, Park EJ. Connexins and Integrins in Exosomes. Cancers (Basel). 2019;11:1.

23. Valadi H, Ekstrom K, Bossios A, Sjostrand M, Lee JJ, Lotvall JO. Exosomemediated transfer of mRNAs and microRNAs is a novel mechanism of genetic exchange between cells. Nat Cell Biol. 2007;9(6):654-9.

24. Colombo M, Raposo G, Thery C. Biogenesis, secretion, and intercellular interactions of exosomes and other extracellular vesicles. Annu Rev Cell Dev Biol. 2014:30:255-89.

25. Xu L, Gimple RC, Lau WB, Lau B, Fei F, Shen Q, et al. The present and future of the mass spectrometry-based investigation of the exosome landscape. Mass Spectrom Rev. 2020;39(5-6):745-62.

26. Muluhngwi P, Valdes R Jr, Fernandez-Botran R, Burton E, Williams B, Linder MW. Cell-free DNA diagnostics: current and emerging applications in oncology. Pharmacogenomics. 2019:20(5):357-80.

27. Giallombardo M, Chacartegui Borras J, Castiglia M, Van Der Steen N, Mertens I, Pauwels P, et al. Exosomal miRNA analysis in non-small cell lung Cancer (NSCLC) Patients' plasma through qPCR: a feasible liquid biopsy tool. J Vis Exp. 2016;111.

28. Weidle UH, Birzele F, Kollmorgen G, Ruger R. The multiple roles of Exosomes in metastasis. Cancer Genomics Proteomics. 2017;14(1):1-15.

29. Faught E, Henrickson L, Vijayan MM. Plasma exosomes are enriched in $\mathrm{Hsp} 70$ and modulated by stress and cortisol in rainbow trout. J Endocrinol. 2017:232(2):237-46.

30. Yunusova NV, Tugutova EA, Tamkovich SN, Kondakova IV. The role of exosomal tetraspanins and proteases in tumor progression. Biomed Khim. 2018;64(2):123-33.

31. Pegtel DM, Gould SJ. Exosomes. Annu Rev Biochem. 2019;88:487-514.

32. Skotland T, Hessvik NP, Sandvig K, Llorente A. Exosomal lipid composition and the role of ether lipids and phosphoinositides in exosome biology. J Lipid Res. 2019;60(1):9-18.
33. Trajkovic K, Hsu C, Chiantia S, Rajendran L, Wenzel D, Wieland F, et al. Ceramide triggers budding of exosome vesicles into multivesicular endosomes. Science. 2008:319(5867):1244-7.

34. Kajimoto T, Okada T, Miya S, Zhang L, Nakamura S. Ongoing activation of sphingosine 1-phosphate receptors mediates maturation of exosomal multivesicular endosomes. Nat Commun. 2013;4:2712.

35. Ibrahim A, Marban E. Exosomes: fundamental biology and roles in cardiovascular physiology. Annu Rev Physiol. 2016;78:67-83.

36. Wei Z, Batagov AO, Schinelli S, Wang J, Wang Y, El Fatimy R, et al. Coding and noncoding landscape of extracellular RNA released by human glioma stem cells. Nat Commun. 2017:8(1):1145.

37. Gibbings DJ, Ciaudo C, Erhardt M, Voinnet O. Multivesicular bodies associate with components of miRNA effector complexes and modulate miRNA activity. Nat Cell Biol. 2009;11(9):1143-9.

38. Zaborowski MP, Balaj L, Breakefield XO, Lai CP. Extracellular vesicles: composition, biological relevance, and methods of study. Bioscience. 2015;65(8):783-97.

39. Tang $X H$, Guo T, Gao XY, Wu XL, Xing XF, Ji JF, et al. Exosome-derived noncoding RNAs in gastric cancer: functions and clinical applications. Mol Cancer. 2021;20(1):99.

40. Sun W, Ren Y, Lu Z, Zhao X. The potential roles of exosomes in pancreatic cancer initiation and metastasis. Mol Cancer. 2020;19(1):135.

41. Fujita Y, Kosaka N, Araya J, Kuwano K, Ochiya T. Extracellular vesicles in lung microenvironment and pathogenesis. Trends Mol Med. 2015;21(9):533-42.

42. Frydrychowicz M, Kolecka-Bednarczyk A, Madejczyk M, Yasar S, Dworacki G. Exosomes - structure, biogenesis and biological role in non-small-cell lung cancer. Scand J Immunol. 2015;81(1):2-10.

43. Hoshino A, Costa-Silva B, Shen TL, Rodrigues G, Hashimoto A, Tesic Mark $\mathrm{M}$, et al. Tumour exosome integrins determine organotropic metastasis. Nature. 2015:527(7578):329-35.

44. Mashouri L, Yousefi H, Aref AR, Ahadi AM, Molaei F, Alahari SK. Exosomes: composition, biogenesis, and mechanisms in cancer metastasis and drug resistance. Mol Cancer. 2019;18(1):75.

45. Conlan RS, Pisano S, Oliveira MI, Ferrari M, Mendes PI. Exosomes as reconfigurable therapeutic systems. Trends Mol Med. 2017;23(7):636-50.

46. Yue P, Zhang Y, Mei K, Wang S, Lesigang J, Zhu Y, et al. Sec3 promotes the initial binary t-SNARE complex assembly and membrane fusion. Nat Commun. 2017:8:14236

47. Wei Y, Wang D, Jin F, Bian Z, Li L, Liang H, et al. Pyruvate kinase type M2 promotes tumour cell exosome release via phosphorylating synaptosome-associated protein 23. Nat Commun. 2017;8:14041.

48. Wang Y, Li L, Hou C, Lai Y, Long J, Liu J, et al. SNARE-mediated membrane fusion in autophagy. Semin Cell Dev Biol. 2016;60:97-104.

49. Lepore DM, Martinez-Nunez L, Munson M. Exposing the elusive exocyst structure. Trends Biochem Sci. 2018:43(9):714-25.

50. Pfeffer SR. Two Rabs for exosome release. Nat Cell Biol. 2010;12(1):3-4.

51. Ostrowski M, Carmo NB, Krumeich S, Fanget I, Raposo G, Savina A, et al. Rab27a and Rab27b control different steps of the exosome secretion pathway. Nat Cell Biol. 2010;12(1):19-30 sup pp 1-13.

52. Zeng Y, Yao X, Liu X, He X, Li L, Liu X, et al. Anti-angiogenesis triggers exosomes release from endothelial cells to promote tumor vasculogenesis. J Extracell Vesicles. 2019;8(1):1629865.

53. Beatriz M, Vilaca R, Lopes C. Exosomes: innocent bystanders or critical culprits in neurodegenerative diseases. Front Cell Dev Biol. 2021:9:635104.

54. Wang J, Yao Y, Chen X, Wu J, Gu T, Tang X. Host derived exosomespathogens interactions: potential functions of exosomes in pathogen infection. Biomed Pharmacother. 2018:108:1451-9.

55. Baharlooi H, Azimi M, Salehi Z, Izad M. Mesenchymal stem cell-derived Exosomes: a promising therapeutic ace card to address autoimmune diseases. Int J Stem Cells. 2020;13(1):13-23.

56. Yu W, Hurley J, Roberts D, Chakrabortty SK, Enderle D, Noerholm M, et al. Exosome-based liquid biopsies in cancer: opportunities and challenges. Ann Oncol. 2021;32(4):466-77.

57. French KC, Antonyak MA, Cerione RA. Extracellular vesicle docking at the cellular port: extracellular vesicle binding and uptake. Semin Cell Dev Biol. 2017;67:48-55. 
58. Vaswani K, Koh YQ, Almughlliq FB, Peiris HN, Mitchell MD. A method for the isolation and enrichment of purified bovine milk exosomes. Reprod Biol. 2017;17(4):341-8.

59. Thery C, Witwer KW, Aikawa E, Alcaraz MJ, Anderson JD, Andriantsitohaina $\mathrm{R}$, et al. Minimal information for studies of extracellular vesicles 2018 (MISEV2018): a position statement of the International Society for Extracellular Vesicles and update of the MISEV2014 guidelines. J Extracell Vesicles. 2018;7(1):1535750.

60. Witwer KW, Soekmadji C, Hill AF, Wauben MH, Buzas El, Di Vizio D, et al. Updating the MISEV minimal requirements for extracellular vesicle studies: building bridges to reproducibility. J Extracell Vesicles. 2017;6(1):1396823.

61. Baek R, Jorgensen MM. Multiplexed Phenotyping of small extracellular vesicles using protein microarray (EV Array). Methods Mol Biol. 2017;1545:117-27.

62. Sina AA, Vaidyanathan R, Dey S, Carrascosa LG, Shiddiky MJ, Trau M. Real time and label free profiling of clinically relevant exosomes. Sci Rep. 2016;6:30460.

63. He YD, Tao W, He T, Wang BY, Tang XM, Zhang LM, et al. A urine extracellular vesicle circRNA classifier for detection of high-grade prostate cancer in patients with prostate-specific antigen $2-10 \mathrm{ng} / \mathrm{mL}$ at initial biopsy. Mol Cancer. 2021;20(1):96.

64. Ocansey DKW, Zhang L, Wang Y, Yan Y, Qian H, Zhang X, et al. Exosomemediated effects and applications in inflammatory bowel disease. Biol Rev Camb Philos Soc. 2020;95(5):1287-307.

65. Hu Q, Su H, Li J, Lyon C, Tang W, Wan M, et al. Clinical applications of exosome membrane proteins. Precis Clin Med. 2020:3(1):54-66.

66. Chen KB, Chen J, Jin XL, Huang Y, Su QM, Chen L. Exosome-mediated peritoneal dissemination in gastric cancer and its clinical applications. Biomed Rep. 2018;8(6):503-9.

67. Kahlert C, Kalluri R. Exosomes in tumor microenvironment influence cancer progression and metastasis. J Mol Med (Berl). 2013;91(4):431-7.

68. Wang L, Yang G, Zhao D, Wang J, Bai Y, Peng Q, et al. CD103-positive CSC exosome promotes EMT of clear cell renal cell carcinoma: role of remote MiR-19b-3p. Mol Cancer. 2019;18(1):86.

69. Choi D, Lee TH, Spinelli C, Chennakrishnaiah S, D'Asti E, Rak J. Extracellular vesicle communication pathways as regulatory targets of oncogenic transformation. Semin Cell Dev Biol. 2017:67:11-22.

70. Grange C, Tapparo M, Collino F, Vitillo L, Damasco C, Deregibus MC, et al. Microvesicles released from human renal cancer stem cells stimulate angiogenesis and formation of lung premetastatic niche. Cancer Res. 2011;71(15):5346-56.

71. Chen G, Zhang Y, Wu X. 786-0 renal cancer cell line-derived exosomes promote 786-0 cell migration and invasion in vitro. Oncol Lett. 2014;7(5):1576-80.

72. Hou Y, Fan L, Li H. Oncogenic miR-27a delivered by exosomes binds to SFRP1 and promotes angiogenesis in renal clear cell carcinoma. Mol Ther Nucleic Acids. 2021;24:92-103.

73. Raimondo F, Morosi L, Corbetta S, Chinello C, Brambilla P, Della Mina $P$, et al. Differential protein profiling of renal cell carcinoma urinary exosomes. Mol BioSyst. 2013;9(6):1220-33.

74. Zhang Y, Luo CL, He BC, Zhang JM, Cheng G, Wu XH. Exosomes derived from IL-12-anchored renal cancer cells increase induction of specific antitumor response in vitro: a novel vaccine for renal cell carcinoma. Int J Oncol. 2010;36(1):133-40.

75. Gao Y, Xu H, Li N, Wang H, Ma L, Chen S, et al. Renal cancer-derived exosomes induce tumor immune tolerance by MDSCs-mediated antigen-specific immunosuppression. Cell Commun Signal. 2020;18(1):106.

76. Demircioglu F, Hodivala-Dilke K. alphavbeta3 integrin and tumour blood vessels-learning from the past to shape the future. Curr Opin Cell Biol. 2016:42:121-7.

77. Zhang L, Wu X, Luo C, Chen X, Yang L, Tao J, et al. The 786-0 renal cancer cell-derived exosomes promote angiogenesis by downregulating the expression of hepatocyte cell adhesion molecule. Mol Med Rep. 2013;8(1):272-6.

78. Audia A, Conroy S, Glass R, Bhat KPL. The impact of the tumor microenvironment on the properties of Glioma stem-like cells. Front Oncol. 2017:7:143.

79. Urabe F, Kosaka N, Kimura T, Egawa S, Ochiya T. Extracellular vesicles: toward a clinical application in urological cancer treatment. Int J Urol. 2018:25(6):533-43.
80. Xue C, Shen Y, Li X, Li B, Zhao S, Gu J, et al. Exosomes derived from hypoxia-treated human adipose Mesenchymal stem cells enhance angiogenesis through the PKA signaling pathway. Stem Cells Dev. 2018;27(7):456-65.

81. Grange C, Brossa A, Bussolati B. Extracellular Vesicles and Carried miRNAs in the Progression of Renal Cell Carcinoma. Int J Mol Sci. 2019;20:8.

82. Jingushi K, Uemura M, Ohnishi N, Nakata W, Fujita K, Naito T, et al. Extracellular vesicles isolated from human renal cell carcinoma tissues disrupt vascular endothelial cell morphology via azurocidin. Int J Cancer. 2018;142(3):607-17.

83. Xuan Z, Chen C, Tang W, Ye S, Zheng J, Zhao Y, et al. TKI-resistant renal Cancer secretes low-level Exosomal miR-549a to induce vascular permeability and angiogenesis to promote tumor metastasis. Front Cell Dev Biol. 2021;9:689947.

84. Li YL, Wu LW, Zeng LH, Zhang ZY, Wang W, Zhang C, et al. ApoC1 promotes the metastasis of clear cell renal cell carcinoma via activation of STAT3. Oncogene. 2020;39(39):6203-17.

85. Horie K, Kawakami K, Fujita Y, Sugaya M, Kameyama K, Mizutani K, et al. Exosomes expressing carbonic anhydrase 9 promote angiogenesis. Biochem Biophys Res Commun. 2017:492(3):356-61.

86. Lugano R, Ramachandran M, Dimberg A. Tumor angiogenesis: causes, consequences, challenges and opportunities. Cell Mol Life Sci. 2020;77(9):1745-70.

87. Umansky V, Blattner C, Fleming V, Hu X, Gebhardt C, Altevogt P, et al. Myeloid-derived suppressor cells and tumor escape from immune surveillance. Semin Immunopathol. 2017;39(3):295-305.

88. Shao L, Zhang B, Wang L, Wu L, Kan Q, Fan K. MMP-9-cleaved osteopontin isoform mediates tumor immune escape by inducing expansion of myeloid-derived suppressor cells. Biochem Biophys Res Commun. 2017:493(4):1478-84.

89. Diao J, Yang X, Song X, Chen S, He Y, Wang Q, et al. Exosomal Hsp70 mediates immunosuppressive activity of the myeloid-derived suppressor cells via phosphorylation of Stat3. Med Oncol. 2015;32(2):453.

90. Frankenberger B, Noessner E, Schendel DJ. Immune suppression in renal cell carcinoma. Semin Cancer Biol. 2007;17(4):330-43.

91. Hinkel A, Tso CL, Gitlitz BJ, Neagos N, Schmid I, Paik SH, et al. Immunomodulatory dendritic cells generated from nonfractionated bulk peripheral blood mononuclear cell cultures induce growth of cytotoxic T cells against renal cell carcinoma. J Immunother. 2000;23(1):83-93.

92. Yang SH, Lee JP, Jang HR, Cha RH, Han SS, Jeon US, et al. Sulfatidereactive natural killer T cells abrogate ischemia-reperfusion injury. J Am Soc Nephrol. 2011;22(7):1305-14.

93. Xia Y, Zhang Q, Zhen Q, Zhao Y, Liu N, Li T, et al. Negative regulation of tumor-infiltrating NK cell in clear cell renal cell carcinoma patients through the exosomal pathway. Oncotarget. 2017;8(23):37783-95.

94. Yang C, Robbins PD. The roles of tumor-derived exosomes in cancer pathogenesis. Clin Dev Immunol. 2011;2011:842849.

95. Yu DD, Wu Y, Shen HY, Lv MM, Chen WX, Zhang XH, et al. Exosomes in development, metastasis and drug resistance of breast cancer. Cancer Sci. 2015;106(8):959-64.

96. Yang L, Wu X, Wang D, Luo C, Chen L. Renal carcinoma cell-derived exosomes induce human immortalized line of Jurkat T lymphocyte apoptosis in vitro. Urol Int. 2013;91(3):363-9.

97. Sceneay J, Smyth MJ, Moller A. The pre-metastatic niche: finding common ground. Cancer Metastasis Rev. 2013:32(3-4):449-64.

98. Liu Y, Cao X. Characteristics and significance of the pre-metastatic niche. Cancer Cell. 2016;30(5):668-81.

99. Ingangi V, Minopoli M, Ragone C, Motti ML, Carriero MV. Role of microenvironment on the fate of disseminating Cancer stem cells. Front Oncol. 2019:9:82.

100. Valcz G, Buzas El, Szallasi Z, Kalmar A, Krenacs T, Tulassay Z, et al. Perspective: bidirectional exosomal transport between cancer stem cells and their fibroblast-rich microenvironment during metastasis formation. NPJ Breast Cancer. 2018:4:18.

101. Whiteside TL. Tumor-derived Exosomes and their role in Cancer progression. Adv Clin Chem. 2016;74:103-41.

102. Tsuruda M, Yoshino H, Okamura S, Kuroshima K, Osako Y, Sakaguchi $T$, et al. Oncogenic effects of RAB27B through exosome independent function in renal cell carcinoma including sunitinib-resistant. PLoS One. 2020;15(5):e0232545. 
103. Rhoads RE. Synthetic mRNA: production, introduction into cells, and physiological consequences. Methods Mol Biol. 2016;1428:3-27.

104. Gilbert WV, Bell TA, Schaening C. Messenger RNA modifications: form, distribution, and function. Science. 2016;352(6292):1408-12.

105. De Palma G, Sallustio F, Curci C, Galleggiante V, Rutigliano M, Serino $G$, et al. The three-gene signature in urinary extracellular vesicles from patients with clear cell renal cell carcinoma. J Cancer. 2016;7(14):1960-7.

106. Di Leva G, Garofalo M, Croce CM. MicroRNAs in cancer. Annu Rev Pathol. 2014;9:287-314

107. Hirschberger S, Hinske LC, Kreth S. MiRNAs: dynamic regulators of immune cell functions in inflammation and cancer. Cancer Lett. 2018:431:11-21.

108. Frixa T, Donzelli S, Blandino G. Oncogenic MicroRNAs: key players in malignant transformation. Cancers (Basel). 2015;7(4):2466-85.

109. Zhang B, Pan X, Cobb GP, Anderson TA. microRNAs as oncogenes and tumor suppressors. Dev Biol. 2007;302(1):1-12.

110. Zhang W, Ni M, Su Y, Wang H, Zhu S, Zhao A, et al. MicroRNAs in serum Exosomes as potential biomarkers in clear-cell renal cell carcinoma. Eur Urol Focus. 2018:4(3):412-9.

111. Xiao CT, Lai WJ, Zhu WA, Wang H. MicroRNA derived from circulating Exosomes as noninvasive biomarkers for diagnosing renal cell carcinoma. Onco Targets Ther. 2020;13:10765-74.

112. Song $\mathrm{S}$, Long $\mathrm{M}$, Yu G, Cheng Y, Yang $\mathrm{Q}$, Liu J, et al. Urinary exosome miR-30c-5p as a biomarker of clear cell renal cell carcinoma that inhibits progression by targeting HSPA5. J Cell Mol Med. 2019;23(10):6755-65.

113. Du M, Giridhar KV, Tian Y, Tschannen MR, Zhu J, Huang CC, et al. Plasma exosomal miRNAs-based prognosis in metastatic kidney cancer. Oncotarget. 2017;8(38):63703-14.

114. Kurahashi R, Kadomatsu T, Baba M, Hara C, Itoh H, Miyata K, et al. MicroRNA-204-5p: a novel candidate urinary biomarker of Xp11.2 translocation renal cell carcinoma. Cancer Sci. 2019;110(6):1897-908.

115. Crentsil VC, Liu H, Sellitti DF. Comparison of exosomal microRNAs secreted by 786-O clear cell renal carcinoma cells and HK-2 proximal tubule-derived cells in culture identifies microRNA-205 as a potential biomarker of clear cell renal carcinoma. Oncol Lett. 2018;16(1):1285-90.

116. Li DY, Lin FF, Li GP, Zeng FC. Exosomal microRNA-15a from ACHN cells aggravates clear cell renal cell carcinoma via the BTG2/PI3K/AKT axis. Kaohsiung J Med Sci. 2021.

117. Wang X, Wang T, Chen C, Wu Z, Bai P, Li S, et al. Serum exosomal miR210 as a potential biomarker for clear cell renal cell carcinoma. J Cell Biochem. 2018.

118. Butz H, Nofech-Mozes R, Ding Q, Khella HWZ, Szabo PM, Jewett M, et al. Exosomal MicroRNAs are diagnostic biomarkers and can mediate cell-cell communication in renal cell carcinoma. Eur Urol Focus. 2016;2(2):210-8.

119. Chan JJ, Tay Y. Noncoding RNA:RNA Regulatory Networks in Cancer. Int J Mol Sci. 2018;19:5.

120. Cech TR, Steitz JA. The noncoding RNA revolution-trashing old rules to forge new ones. Cell. 2014;157(1):77-94.

121. Qi P, Zhou XY, Du X. Circulating long non-coding RNAs in cancer: current status and future perspectives. Mol Cancer. 2016;15(1):39.

122. Naderi-Meshkin H, Lai X, Amirkhah R, Vera J, Rasko JEJ, Schmitz U. Exosomal IncRNAs and cancer: connecting the missing links. Bioinformatics. 2019:35(2):352-60.

123. Wang Y, Zhang M, Zhou F. Biological functions and clinical applications of exosomal long non-coding RNAs in cancer. J Cell Mol Med. 2020;24(20):11656-66.

124. Yang G, Lu X, Yuan L. LncRNA: a link between RNA and cancer. Biochim Biophys Acta. 2014;1839(11):1097-109.

125. Qu L, Ding J, Chen C, Wu ZJ, Liu B, Gao Y, et al. Exosome-transmitted IncARSR promotes Sunitinib resistance in renal Cancer by acting as a competing endogenous RNA. Cancer Cell. 2016;29(5):653-68.

126. Salzman J, Chen RE, Olsen MN, Wang PL, Brown PO. Cell-type specific features of circular RNA expression. PLoS Genet. 2013;9(9):e1003777.

127. Memczak S, Jens M, Elefsinioti A, Torti F, Krueger J, Rybak A, et al. Circular RNAs are a large class of animal RNAs with regulatory potency. Nature. 2013;495(7441):333-8.

128. Mao W, Huang X, Wang L, Zhang Z, Liu M, Li Y, et al. Circular RNA hsa_circ_0068871 regulates FGFR3 expression and activates STAT3 by targeting miR-181a-5p to promote bladder cancer progression. J Exp Clin Cancer Res. 2019;38(1):169.

129. Li Y, Zheng Q, Bao C, Li S, Guo W, Zhao J, et al. Circular RNA is enriched and stable in exosomes: a promising biomarker for cancer diagnosis. Cell Res. 2015;25(8):981-4.

130. Zhang PF, Wei CY, Huang XY, Peng R, Yang X, Lu JC, et al. Circular RNA circTRIM33-12 acts as the sponge of MicroRNA-191 to suppress hepatocellular carcinoma progression. Mol Cancer. 2019;18(1):105.

131. Xiao H, Shi J. Exosomal circular RNA 400068 promotes the development of renal cell carcinoma via the miR2105p/SOCS1 axis. Mol Med Rep. 2020;22(6):4810-20.

132. Sun W, Luo JD, Jiang H, Duan DD. Tumor exosomes: a double-edged sword in cancer therapy. Acta Pharmacol Sin. 2018;39(4):534-41.

133. Azmi AS, Bao B, Sarkar FH. Exosomes in cancer development, metastasis, and drug resistance: a comprehensive review. Cancer Metastasis Rev. 2013;32(3-4):623-42.

134. Motzer RJ, Hutson TE, Tomczak P, Michaelson MD, Bukowski RM, Rixe O, et al. Sunitinib versus interferon alfa in metastatic renal-cell carcinoma. N Engl J Med. 2007;356(2):115-24.

135. Rini BI, Atkins MB. Resistance to targeted therapy in renal-cell carcinoma. Lancet Oncol. 2009;10(10):992-1000.

136. Qin Z, Xu Q, Hu H, Yu L, Zeng S. Extracellular vesicles in renal cell carcinoma: multifaceted roles and potential applications identified by experimental and computational methods. Front Oncol. 2020;10:724.

137. Barile L, Vassalli G. Exosomes: therapy delivery tools and biomarkers of diseases. Pharmacol Ther. 2017;174:63-78.

138. He C, Zheng S, Luo Y, Wang B. Exosome Theranostics: biology and translational medicine. Theranostics. 2018;8(1):237-55.

139. Sun D, Zhuang X, Zhang S, Deng ZB, Grizzle W, Miller D, et al. Exosomes are endogenous nanoparticles that can deliver biological information between cells. Adv Drug Deliv Rev. 2013;65(3):342-7.

140. Yuan D, Zhao Y, Banks WA, Bullock KM, Haney M, Batrakova E, et al. Macrophage exosomes as natural nanocarriers for protein delivery to inflamed brain. Biomaterials. 2017;142:1-12.

141. Record M, Carayon K, Poirot M, Silvente-Poirot S. Exosomes as new vesicular lipid transporters involved in cell-cell communication and various pathophysiologies. Biochim Biophys Acta. 2014;1841(1):108-20.

142. Kim MS, Haney MJ, Zhao Y, Yuan D, Deygen I, Klyachko NL, et al. Engineering macrophage-derived exosomes for targeted paclitaxel delivery to pulmonary metastases: in vitro and in vivo evaluations. Nanomedicine. 2018;14(1):195-204.

143. Liang G, Zhu Y, Ali DJ, Tian T, Xu H, Si K, et al. Engineered exosomes for targeted co-delivery of miR-21 inhibitor and chemotherapeutics to reverse drug resistance in colon cancer. J Nanobiotechnology. 2020;18(1):10

144. Qian L, Yu S, Chen Z, Meng Z, Huang S, Wang P. Functions and clinical implications of exosomes in pancreatic cancer. Biochim Biophys Acta Rev Cancer. 2019;1871(1):75-84.

145. Ha D, Yang N, Nadithe V. Exosomes as therapeutic drug carriers and delivery vehicles across biological membranes: current perspectives and future challenges. Acta Pharm Sin B. 2016;6(4):287-96.

146. Zhong X, Zhou Y, Cao Y, Ding J, Wang P, Luo Y, et al. Enhanced antitumor efficacy through microwave ablation combined with a dendritic cellderived exosome vaccine in hepatocellular carcinoma. Int J Hyperth. 2020:37(1):1210-8.

147. Zhang Y, Wu XH, Luo CL, Zhang JM, He BC, Chen G. Interleukin-12-anchored exosomes increase cytotoxicity of T lymphocytes by reversing the JAK/STAT pathway impaired by tumor-derived exosomes. Int J Mol Med. 2010;25(5):695-700.

148. Zhang Y, Wu XH, Chen G, Luo CL, Zhang JM. Preparation of renal cancer vaccine of IL-12-anchored exosomes and its antitumor effect in vitro. Zhonghua Zhong Liu Za Zhi. 2010;32(5):339-43.

149. Gu X, Erb U, Buchler MW, Zoller M. Improved vaccine efficacy of tumor exosome compared to tumor lysate loaded dendritic cells in mice. Int J Cancer. 2015;136(4):E74-84.

150. Krause M, Samoylenko A, Vainio SJ. Exosomes as renal inductive signals in health and disease, and their application as diagnostic markers and therapeutic agents. Front Cell Dev Biol. 2015;3:65.

151. Xu HY, Li N, Yao N, XU XF, Wang HX, Liu XY, et al. CD8+ T cells stimulated by exosomes derived from RenCa cells mediate specific immune responses through the FasL/Fas signaling pathway and, combined with 
GMCSF and IL12, enhance the antirenal cortical adenocarcinoma effect. Oncol Rep. 2019;42(2):866-79.

152. Franzen CA, Blackwell RH, Foreman KE, Kuo PC, Flanigan RC, Gupta GN. Urinary Exosomes: the potential for biomarker utility, intercellular signaling and therapeutics in urological malignancy. J Urol. 2016;195(5):1331-9.

\section{Publisher's Note}

Springer Nature remains neutral with regard to jurisdictional claims in published maps and institutional affiliations.
Ready to submit your research? Choose BMC and benefit from:

- fast, convenient online submission

- thorough peer review by experienced researchers in your field

- rapid publication on acceptance

- support for research data, including large and complex data types

- gold Open Access which fosters wider collaboration and increased citations

- maximum visibility for your research: over 100M website views per year

At BMC, research is always in progress.

Learn more biomedcentral.com/submissions 